\title{
Driving business performance: innovation complementarities and persistence patterns
}

Eleonora Bartoloni

Maurizio Baussola

Quaderno n. 113/marzo 2016 


\title{
DIPARTIMENTO DI SCIENZE ECONOMICHE E SOCIALI
}

\section{Driving business performance: innovation complementarities and persistence patterns *}

\author{
Eleonora Bartolonit \\ Maurizio Baussola
}

Quaderno n. 113/marzo 2016

\section{VP VIta e PENSIERo}

* This paper is a result of collaboration between the Italian National Institute of Statistics (ISTAT, Regional Office for Lombardy) and Università Cattolica del Sacro Cuore (UCSC). We would like to thank Manlio Calzaroni, Raffaele Malizia and Rosalia Coniglio of the Italian National Institute of Statistics (ISTAT) for providing access to the data. Needless to say, the usual disclaimers apply.

* ISTAT, Italian National Institute of Statistics, Via Porlezza, 12, Milano 20123, Italy. E-mail: bartolon@istat.it.

* UCSC, Università Cattolica del Sacro Cuore, Via Emilia Parmense 12, Piacenza 29100, Italy. E-mail: maurizio.baussola@unicatt.it. 
Eleonora Bartoloni, ISTAT, Italian National Institute of Statistics, Via Porlezza, 12, 20123 Milano

Maurizio Baussola, Dipartimento di Scienze Economiche e Sociali, Università Cattolica del Sacro Cuore, Piacenza

$\triangle$ bartolon@istat.it

maurizio.baussola@unicatt.it

I quaderni possono essere richiesti a:

Dipartimento di Scienze Economiche e Sociali, Università Cattolica del Sacro Cuore

Via Emilia Parmense 84 - 29122 Piacenza - Tel. 0523599.342

http://dipartimenti.unicatt.it/dises

$\triangle$ dises-pc@unicatt.it

www.vitaepensiero.it

All rights reserved. Photocopies for personal use of the reader, not exceeding $15 \%$ of each volume, may be made under the payment of a copying fee to the SIAE, in accordance with the provisions of the law n. 633 of 22 april 1941 (art. 68, par. 4 and 5). Reproductions which are not intended for personal use may be only made with the written permission of CLEARedi, Centro Licenze e Autorizzazioni per le Riproduzioni Editoriali, Corso di Porta Romana 108, 20122 Milano, e-mail: autorizzazioni@clearedi.org,web site www.clearedi.org.

Le fotocopie per uso personale del lettore possono essere effettuate nei limiti del 15\% di ciascun volume dietro pagamento alla SIAE del compenso previsto dall'art. 68, commi 4 e 5, della legge 22 aprile 1941 n. 633.

Le fotocopie effettuate per finalità di carattere professionale, economico o commerciale o comunque per uso diverso da quello personale possono essere effettuate a seguito di specifica autorizzazione rilasciata da CLEARedi, Centro Licenze e Autorizzazioni per le Riproduzioni Editoriali, Corso di Porta Romana 108, 20122 Milano, e-mail: autorizzazioni@clearedi.org e sito web www.clearedi.org.

\section{(C) 2016 Eleonora Bartoloni, Maurizio Baussola ISBN 978-88-343-3194-1}




\begin{abstract}
Complementarities between technological and non-technological innovation are crucial determinants of firm performance. This topic has not received the attention that it merits, as the focus has been primarily placed on technological innovation alone or on innovation efforts as measured by $R \& D$ or patent activities. The capacities to develop market-oriented behaviour and introduce new organisational innovations are the drivers - together with technological innovation - of a firm's productivity and profitability. We also underline how the impact of such activities is larger when they persist over time, thus introducing a more general concept of innovation persistency. We present an empirical model based on a large and new panel of Italian manufacturing firms covering the period 2000-2012 that enables us to derive the precise impacts of a firm's innovative effort - based on a broad definition that incorporates non-technological innovation and persistence - on its productivity and profitability.
\end{abstract}

JEL Classifications: L25, 030, 032, 033

Keywords: Technological and non-technological innovation, Complementarities, European Community Innovation Survey, Profitability, Productivity, Unbalanced panel data 



\section{Introduction}

The relationship between innovation and firms' performance has long been debated within the economic and managerial literature. The former has focused on both macro- and microeconomic implications underlining, on the one hand, the role of innovation inputs (e.g., R\&D activity) in determining long-run economic growth. This approach characterised the early R\&D endogenous growth models (Romer, 1990; Jones, 1995; Aghion and Howitt, 1992).

On the other hand, the microeconomic approach has focused particularly on the empirical estimation of the impact of innovation on firms' productivity (Geroski, 1989; Crépon et al., 1998; Lööf and Heshmati, 2002), thus emphasising the methodological issues underlying such empirical investigations.

On the managerial side, particular emphasis has been devoted to the impact of a firm's attitude of being an innovator (product and or process) and, simultaneously, to its ability to be market-oriented (Roberts, 2001; Narver and Slater, 1990). This approach embraces a more comprehensive definition of an innovative attitude, which typically brings about other forms of non-technological innovations, i.e., organisational and marketing innovations. Indeed, these forms of innovation play a crucial role in affecting firms' performance in terms of productivity and even profitability, in that the innovation process affects the internal allocation and use of resources, thus enabling innovating firms to be more responsive to changing market conditions (Geroski et al., 1993).

All of these issues imply that for innovation to be effective, it should be persistent, thus enabling those continuously innovating firms to gain a premium with respect to peers that do not act accordingly. This view is also supported on theoretical grounds by theories addressing i) the existence of sunk costs in innovation activities (e.g., R\&D expenditures) (Stiglitz, 1987; Mañez et al., 2009); ii) the positive correlation with past successful innovations (success-breeds-success), which implies a positive impact on firms' profitability and thus on their future ability to finance more innovative activities (Le Bas and Latham, 2006; Carpenter and Petersen, 2002); and iii) the dynamic accumulation of knowledge or, in other words, the dynamic process of innovation that enables a firm to learn and adapt its innovation strategy (Geroski et al., 1993, 1997; David, 1992).

Innovation persistence provides a firm with the ability to exploit competitive advantages with respect to competitors and thus to earn 
profits that are systematically higher than those gained by non-innovating or at least only occasional innovating firms. (Bartoloni and Baussola, 2009; Mueller, 1992).

However, the role of non-technological innovation has not been completely considered in this framework. Indeed, non-technological innovation is crucially associated with technological innovation (e.g., product or process innovation) and generates technological activities related to new organisational and marketing activities, which affect the success of such new technological practices. In particular, process innovation and organisation innovation may be closely linked to one another, whereas product innovation may be more effectively related (although not exclusively) to marketing innovation. In a recent study, Bartoloni and Baussola (2016) underline how an emphasis on technological innovation alone is misleading and that a firm's decision to innovate involves a more complex and general process that crucially affects its performance.

We propose an empirical investigation in which we explicitly consider the role of persistent technological and non-technological innovations in affecting firms' performance in terms of productivity and profitability. We use a panel of Italian manufacturing firms over the period 1998-2012 derived from the Community Innovation Survey and matched with administrative data that enabled us to obtain information on firms' balance sheets.

The paper is therefore structured as follows. In Section 2, we provide the interpretative framework used to develop the empirical analysis. In Section 3, we describe the characteristics of the data set, we present the empirical model in Section 4, and the results are discussed in Section 5. Section 6 concludes the paper.

\section{The interpretative framework}

The debate on the persistence of innovation has typically analysed the role of persistent activities as measured by $R \& D$ (input) or patents (output) and, to a lesser extent, by technology adoption without considering the role of non-technological innovation. The impact of innovation on firms' performance may be analysed with respect to both the input and output of the innovation process. Typically, the former is considered by using $R \& D$ expenditure as a proxy for knowledge capital, which therefore contributes, akin to other production inputs, to 
output growth. Innovation input is also considered, focusing on the adoption of new process technology, which implies the use of new and more efficient capital goods.

This approach has been particularly developed within the endogenous growth theoretical setting (Romer, 1990), in which an R\&D sector interacts with a manufacturing sector producing new capital goods and final output. The model implies an equilibrium growth path crucially depending on the resources allocated to $R \& D$.

Innovation output is considered the key variable that increases productivity in the seminal study by Crépon et al. (1998). In this model, innovation output is measured by expected patents per employee or by the share of innovative sales. This model, which has inspired an increasing number of studies based on such a methodological strategy, is focused on the empirical tools required - when using innovation surveys - to overcome the bias related to information available only for innovative firms.

Lööf and Heshmati (2002) use such an approach to develop an empirical analysis of knowledge capital and productivity at the firm level for a sample of Swedish firms participating in the national Community Innovation Survey. They emphasise how intangible assets are crucial in affecting the results, thus underlining the implicit relevance of their measurement issue.

Another branch of the literature has focused, instead, on panel data investigations to address causality issues (Rouvinen, 2002; Frantzen, 2003; Battisti et al., 2010), finding support for a causal link running from R\&D to productivity.

In our empirical specification, we focus on the relationship between productivity - as measured by real value added per worker - and production inputs while also accounting for the effect of persistently adopted technological and non-technological innovations. Thus, our aim is to investigate whether such a persistent innovative attitude - given by the previous definition that includes technological and non-technological innovations - significantly affects productivity. In addition, we aim to investigate the determinants of firms' profitability. This is the other side of the coin represented by a firm performance measurement.

The relationship between innovation and profitability has received less attention, particularly in recent years, compared with the analysis of the determinants of productivity. The traditional approach to analysing firms' profitability refers to the structure-conduct-performance (SCP) paradigm (Bain, 1956), in that a firm's performance is deter- 
mined by structural characteristics of the industry. In contrast to this approach, the so-called firm efficiency view (Demsetz, 1973; Peltzman, 1977) emphasises the role of firms' characteristics in determining their profits. However, empirical studies have generated controversial results, which crucially depend on the characteristics of the data set used to implement such tests. Slade (2004), Allen (1983), and Delorme Jr. et al. (2002) find support for the SCP approach, whereas Roberts (1999, 2001) and Hawawini et al. (2003) recognise the role of managerial capabilities in determining profitability.

Bartoloni and Baussola (2009) emphasise that the traditional SCP effect, although it was verified in a large panel of Italian manufacturing firms in the 1990s, had a very mild effect on profitability and its persistence, whereas firms' innovative behaviour was more relevant in this respect.

The impact of innovation on profitability has also been analysed in the framework of technology adoption. Geroski et al. (1993) emphasise not only the role of adoption per se but also that such a decision implies a full process that involves other choices and actions within a firm (e.g., organisational changes) that determine different internal allocations of resources.

Mueller and Cubbin (2005) emphasise how technological adoption provides a competitive advantage to innovating firms, thus enabling them to increase their profitability. Technology adoption and profitability is considered in a dynamic perspective by Stoneman and Kwon (1996). They emphasise that multiple adoption may occur, and firms may thus introduce new technologies at different points in time. Profitability - as in the case of technological adoption - should be considered along the diffusion path together with the distinction between older and more recent innovations, as the former are more exposed to greater competition, thus affecting profitability.

Our aim is to conduct an empirical analysis in which the main factors discussed within this framework are considered in the definition of a firm's profitability, as described in Section 4. 


\section{Panel data description}

Our main data source is the Micro-Manu dataset ${ }^{1}$, an unbalanced panel of Italian manufacturing firms linking consecutive waves of the Italian Community Innovation Survey - which forms part of the EU science and technology statistics and is conducted every two years - with the ASIA archive (Statistical Register of Active Businesses) ${ }^{2}$ and an administrative data source providing balance sheets and income statements for those firms included in the CIS samples of respondents. The richness of this data set allows one to enlarge the set of economic indicators typically explored in the innovation survey micro-data and to derive a set of financial and efficiency ratios that are not included in the CIS questionnaire. In accordance with international standards (OECD-Eurostat 2005), firms are classified by their type of innovation activity (technological and non-technological). Information on nontechnological aspects of innovation (new marketing and/or organisational methods) allows one to consider comprehensive innovative activities by focusing on the reciprocal interactions between different aspects of innovation.

To analyse firms' innovative pattern in a longitudinal context, we select an unbalanced panel of firms from the original dataset responding to at least two consecutive non-overlapped ${ }^{3}$ CIS waves (CIS1, years 1998-2000; CIS2, years 2002-2004; CIS4 years 2006-2008; and CIS6, years 2010-2012). We have more than 3,000 firms, corresponding to nearly 8,000 observations over the whole period 1998-2012.

A strictly technological innovating firm is defined as one that has implemented an innovation only in the technological domain (i.e., a product and/or process innovation, with the exclusion of other nontechnological forms of innovation) during the observed period. A complementary innovating firm is defined as one that has innovated in all the technological and non-technological domains (product and process and organisation and marketing). We distinguish between persistent and occasional innovative profiles in both the technological and com-

\footnotetext{
${ }^{1}$ The Micro-Manu dataset is a result of collaboration between the Italian National Institute of Statistics (ISTAT, Regional office for Lombardy) and the Catholic University of the Sacred Hearth.

${ }^{2}$ This archive is the most relevant administrative register used by ISTAT as the basis for many sample surveys and even census investigations.

${ }^{3} \mathrm{~A}$ characteristic that merits attention is that the measurement of the degree of innovation persistence may be over-estimated when two consecutive waves are partially overlapped.
} 
plementary domains by defining (i) a persistent innovator as one that has innovated in at least two consecutive CIS periods (pers_tech and pers_tech_ntech) and (ii) an occasional innovator as one that has innovated at least once during the entire time span but never in two consecutive periods (tech and tech_ntech).

Table 1: Unbalanced panel of manufacturing firms with non-missing accounting information (CIS1, 1998-2000; CIS2, 2002-2004; CIS4, 20062008; CIS6, 2010-2012)

\begin{tabular}{|c|c|c|c|c|c|c|c|}
\hline \multirow{2}{*}{$\begin{array}{c}\text { patterns of } \\
\text { presence }\end{array}$} & \multirow{2}{*}{ obs. } & \multirow{2}{*}{$\begin{array}{l}\text { n. of firms } \\
\text { (average) }\end{array}$} & \multirow{2}{*}{$\begin{array}{c}\text { size (n. of } \\
\text { employees, } \\
\text { median) }\end{array}$} & \multicolumn{4}{|c|}{ firms by innovative behaviour (sample proportion) } \\
\hline & & & & tech_ntech & pers_tech_ntech & tech & pers_tech \\
\hline 0011 & 725 & 363 & 115 & 0.24 & 0.08 & 0.20 & $0 . \overline{0}$ \\
\hline 0110 & 577 & 289 & 74 & 0.20 & 0.04 & 0.24 & 0.04 \\
\hline 0111 & 574 & 191 & 281 & 0.26 & 0.14 & 0.30 & 0.06 \\
\hline 1011 & 287 & 96 & 450 & 0.48 & 0.14 & 0.22 & 0.04 \\
\hline 1100 & 3,331 & 1,666 & 37 & 0.16 & 0.03 & 0.18 & 0.02 \\
\hline 1101 & 633 & 211 & 73 & 0.30 & 0.05 & 0.27 & 0.02 \\
\hline 1110 & 747 & 249 & 116 & 0.27 & 0.11 & 0.28 & 0.03 \\
\hline 1111 & 1,049 & 262 & 365 & 0.37 & 0.24 & 0.26 & 0.10 \\
\hline total & 7,923 & 3,326 & 79 & 0.24 & 0.08 & 0.22 & 0.04 \\
\hline
\end{tabular}

Notes. The patterns of inclusion indicate absence (0) or presence (1), during the four consecutive innovation surveys. Innovative behaviour: tech - the firm has innovated occasionally only in the technological domain; pers_tech - the firm has innovated persistently only in the technological domain; tech_ntech - the firm has innovated occasionally in both the technological and non-technological domains; and pers_tech_ntech - the firm has innovated persistently in both the technological and non-technological domains.

It is worth noting that the specific nature of the CIS's sampling design gives rise to potential selection bias when using a longitudinal framework. Indeed, whereas large firms with more than 250 employees are selected on a census basis, small firms are randomly selected, and this sampling mechanism may negatively affect the probability of a firm being selected in consecutive surveys. Table 1 reports descriptive statistics for each "feasible" pattern of inclusion ${ }^{4}$ relative to the relevant outcomes of a firm's innovative activity. Hence, we can observe, for example, that the mean size of firms that are present only in the first two waves is 37 employees, but the size increases to 365 employees when the balanced sample of firms present in all four waves is considered. If we decided to retain this restricted group, we could define a persistent innovator in a more stringent way (i.e., as one that has continuously

\footnotetext{
${ }^{4}$ According to the methodology proposed by Raymond et al. (2009), a pattern is "feasible" when the dynamics of innovation are potentially observable.
} 
innovated during a four-period time span). However, by following this approach, we would probably confine our analysis to those firms with higher innovative propensity, with possible bias as a result. On the basis of this consideration, we decided to base our empirical investigation on the full set firms appearing in the unbalanced panel.

It is worth emphasising that balance-sheet information for the period 1998-2012 is provided on a yearly basis, whereas the qualitative variables derived from the CIS survey are defined on a three-year basis. To address the problem of different information timing, we averaged accounting information over a three-year period; thus, the economic and financial indexes are provided as average values over the reference CIS time span. One should note that the full samples of firms from the CIS surveys also include small individual firms for which balance-sheet information is not available from the Italian public register; thus, our analysis excludes these firms. We have compared the final sample of firms for which there is complete accounting information to the initial CIS samples in the "feasible" panel and then concluded that the loss of sampling units due to the use of out-of-sample information is negligible. The variables used in the empirical model are described in greater detail below.

\section{Economic performance}

We use a measure of operating profitability, return on sales (ros), that is appropriate for investigating the profitability generated by the core business of a manufacturing firm and a measure of labour productivity $(Y)$, which is given by the value added per employee ratio and may be considered an intermediate measure of a firm's innovation success ${ }^{5}$.

\section{Financial efficiency indexes}

Financial efficiency can be considered by using a measure of a firm's exposure to external financing sources (lev), which is given by the ratio of shareholders' funds to total debt, thus reflecting the extent to which a firm uses internal resources instead of borrowing to finance its activity. Capital deepening

The role of physical capital is captured by considering the capitalto-labour ratio ( $K$, tangible fixed assets per employee). It measures

\footnotetext{
${ }^{5}$ We are aware that the relationship between innovation and productivity produces diverse empirical results. However, following Mohnen and Hall (2013), innovation leads to an increase in productivity, although it is not possible to disentangle the price and output effects on growth, given the characteristics of the available data sets.
} 


\section{Table 2: Descriptive statistics}

\begin{tabular}{|c|c|c|c|c|c|c|c|}
\hline & & period & $\begin{array}{l}1998- \\
2000\end{array}$ & $\begin{array}{l}2002- \\
2004\end{array}$ & $\begin{array}{c}2004- \\
2008\end{array}$ & $\begin{array}{l}2008- \\
2012\end{array}$ & tot. \\
\hline & & n. of observations & 2,462 & 2,855 & 1,471 & 1,135 & 7,923 \\
\hline variable name & type & variable description & & & & & \\
\hline tech_ntech & $0 / 1$ & $\begin{array}{l}1 \text { if the firm has occasionally introduced a technological } \\
\text { innovation in conjunction with a non-technological } \\
\text { innovation }\end{array}$ & 0.22 & 0.21 & 0.28 & 0.30 & 0.24 \\
\hline pers_tech_ntech & $0 / 1$ & $\begin{array}{l}1 \text { if the firm has persistently introduced a technological } \\
\text { innovation in conjunction with a non-technological } \\
\text { innovation }\end{array}$ & 0.07 & 0.06 & 0.12 & 0.13 & 0.08 \\
\hline tech & $0 / 1$ & $\begin{array}{l}1 \text { if the firm has occasionally introduced a technological } \\
\text { innovation }\end{array}$ & 0.21 & 0.22 & 0.25 & 0.25 & 0.22 \\
\hline pers_tech & $0 / 1$ & $\begin{array}{l}1 \text { if the firm has persistently innovated in the } \\
\text { technological domain }\end{array}$ & 0.03 & 0.03 & 0.05 & 0.05 & 0.04 \\
\hline ros & $\mathrm{c}$ & $\begin{array}{l}\text { Return on sales. The ratio between gross operating profits } \\
\text { and sales. An index of operating profitability. }\end{array}$ & 0.12 & 0.11 & 0.10 & 0.09 & 0.11 \\
\hline $\mathrm{Y}$ & $\mathrm{c}$ & Value added per employee (thousands euros) & 59.4 & 60.1 & 71.3 & 74.2 & 64.0 \\
\hline $\mathrm{K}$ & $\mathrm{c}$ & Tangible fixed assets per employee (thousands euros) & 53.1 & 54.5 & 69.7 & 82.8 & 60.9 \\
\hline lev & $\mathrm{c}$ & The ratio of shareholders' funding to total debts & 0.71 & 0.76 & 0.83 & 1.03 & 0.80 \\
\hline $\operatorname{cr} 5$ & $\mathrm{c}$ & Concentration index (Pavitt sectors) $\%$ & 0.33 & 0.35 & 0.26 & 0.29 & 0.30 \\
\hline sect_inntech & $\mathrm{c}$ & Share of sectoral technological innovators $\%$ & 50.1 & 46.8 & 66.0 & 66.2 & 54.2 \\
\hline intern & $0 / 1$ & 1 if the firm sells its products in the international market & 71.0 & 66.9 & 80.1 & 85.6 & 0.7 \\
\hline pavitt_mb & & 1 if in the low and medium-low technology sectors & 0.66 & 0.66 & 0.63 & 0.61 & 0.65 \\
\hline pavitt_ma & & 1 if in the high and medium-high technology sectors & 0.34 & 0.34 & 0.37 & 0.39 & 0.36 \\
\hline AGE & $\mathrm{c}$ & Firm's age (years) & 23 & 26 & 30 & 33 & 27 \\
\hline r\&d & $0 / 1$ & 1 if the firm has undertaken R\&D investments & 0.31 & 0.37 & 0.53 & 0.50 & 0.40 \\
\hline pers_r\&d & $0 / 1$ & $\begin{array}{l}1 \text { if the firm has persistently undertaken } R \& D \\
\text { investments }\end{array}$ & 0.26 & 0.26 & 0.42 & 0.43 & 0.32 \\
\hline gp & $0 / 1$ & 1 if the firm belongs to an industrial group & 0.30 & 0.35 & 0.62 & 0.76 & 0.44 \\
\hline nwest & $0 / 1$ & 1 if the firm is localized in the North-West & 0.35 & 0.36 & 0.39 & 0.36 & 0.36 \\
\hline neast & $0 / 1$ & 1 if the firm is localized in the North-East & 0.34 & 0.34 & 0.35 & 0.36 & 0.34 \\
\hline centre & $0 / 1$ & 1 if the firm is localized in the Centre & 0.16 & 0.16 & 0.13 & 0.14 & 0.15 \\
\hline south & $0 / 1$ & 1 if the firm is localized in the South & 0.15 & 0.15 & 0.13 & 0.14 & 0.14 \\
\hline
\end{tabular}

Notes. The variable $Y$ and $K$ have been deflated using sectoral deflators (base year 2010). "Persistently" means in at least two consecutive periods. "Occasionally" means at least one time but never in two consecutive periods. 
the extent of capital deepening in fostering productivity. Typically, the impact of this variable on labour productivity may be derived from growth-accounting exercises, together with the impact that may be exerted by Total Factor Productivity (TFP). Instead, we test its impact by using an econometric approach, which enables us to consider other possible determinants related, in particular, to a firm's innovative effort. One should note that capital deepening may also incorporate process innovation; this latter determinant typically implies the acquisition of new machinery ${ }^{6}$.

Innovation input

As noted above, together with physical capital, a firm's innovative effort should be considered when describing the core determinants of labour productivity. The proxy that we use, R\&D activities, may also be considered a proxy for knowledge capital, which can contribute directly to labour productivity growth and exert a positive influence through TFP growth. Because we refer to the entire sample of innovative and non-innovative firms, the aforementioned information is not available for this latter group of firms, given the characteristics of the CIS survey. Therefore, we use a dummy variable indicating whether a firm has undertaken $R \& D$ activity occasionally $(R \& D)$ or persistently $(\text { pers_R\&D })^{7}$. Thus, the impact of $\mathrm{R} \& \mathrm{D}$ may be considered a shifting parameter in the adopted specification (see the following Section 4).

Innovation output

The aim of our investigation is to explore the complementary role of technological and non-technological aspects of innovation in determining a firm's performance relative to innovation that is strictly technological. We aim to reveal the presence of possible performance gains that may be earned by firms developing innovation continuously over time compared with sporadic innovators. Thus, we consider the four different proxies for a firm's attitude towards innovation that are described above. As in the case of $\mathrm{R} \& \mathrm{D}$, these variables enter the productivity equation as shifting parameters.

\section{Other firm-specific characteristics}

\footnotetext{
${ }^{6}$ This argument is also considered in Hall et al. (2009), who estimate a productivity equation that depends on product and process innovation together with fixed investment.

${ }^{7}$ Otherwise, a different modelling strategy would have been in order, i.e., focusing only on innovative firms or using a Tobit model with a selection equation. This approach, however, is beyond the scope of our investigation, the aim of which is to specify the different behaviour and performance of innovative and non-innovative firms.
} 
Firms' age (years, log values) may positively affect their growth; thus, firm age exerts an indirect impact on profitability ${ }^{8}$. Moreover, another two variables - available from the CIS survey - reflect a firm's ownership structure and its propensity to internationalise. Thus, we use two dummy variables: the first indicates whether a firm belongs to a corporate group $(g p)$, and the second indicates whether a firm sells its products in the international market (intern). The first variable may affect a firm's efficiency, whereas the latter is closely related to the ability to expand internationally and thus increase turnover.

\section{Sectoral structure and localisation}

Industry-specific characteristics are accounted for by considering two sectoral dummies that, in line with the Pavitt taxonomy, identify the high- and medium-high-technology sectors (pavitt_mh) and the lowand medium-low-technology sectors (pavitt_ml). Geographical characteristics are captured by four regional dummies (nwest, neast, centre, south), reflecting a firm's location in the north-west, north-east, central or southern regions of Italy.

Additionally, we consider the $c r 5$ ratio to capture the SCP mechanism described in Section 2 and the ratio of the sectoral number of technological-innovating firms to the total number of firms in that sector (sect_inntech). Descriptive statistics on the full set of variables are reported in Table 2 .

\section{The empirical model}

We model productivity and profitability using an empirical specification that can be derived from an augmented production function and a profit function.

In particular, productivity, which is defined in terms of real value added per employee, may be derived from equation 1, assuming constant returns to scale ${ }^{9}$.

\footnotetext{
${ }^{8}$ This variable is available from the Statistical Register of Active Businesses (ASIA).

${ }^{9}$ One can specify this equation without imposing constant return to scale. We also estimated such a specification, which provides, however, similar results in terms of capital and shifting factor parameters. A Wald test for constant returns to scale is rejected, but returns to scale are only slightly increasing. Given these issues, we prefer a specification that enables us to explicitly consider the capital deepening factor - which may include a firm's innovative attitude - as a determinant of productivity. Otherwise, we would have had to consider capital and labour separately, thus losing such an interpretation.
} 


$$
y_{i t}=a_{i t}+\beta k_{i t}+u_{i t}
$$

where $y$ is the log of per capita real value added of firm i, $k$ is the $\log$ of physical capital per employee, and $a_{i t}$ is a shifting factor that depends on a firm's attitude towards technological and non-technological innovation and $\mathrm{R} \& \mathrm{D}$ effort. This latter factor also depends on other firms' characteristics that may be relevant in shifting productivity. $u_{i t}$ is a one-way error component:

$$
u_{i t}=\mu_{i}+\epsilon_{i t}
$$

where:

$$
\mu_{i} \sim \operatorname{IID}\left(0, \sigma_{u}^{2}\right) \quad \text { and } \quad \epsilon_{i t} \sim \operatorname{IID}\left(0, \sigma_{\epsilon}^{2}\right)
$$

are independent of each other and themselves. In addition, the error term $\epsilon_{i t}$ is assumed to be white noise, that is:

$$
E\left(\epsilon_{i t}, \epsilon_{i s}\right)=0 \quad \text { for } \quad t \neq s
$$

We account for the persistent innovative attitude of a firm by adopting the definition described in the previous section, i.e., a firm is considered a persistent innovator - from both the strict technological and complementary perspectives (thus including non-technological innovation) - if it has adopted such innovations in at least two consecutive innovation surveys. The persistent R\&D effort may be described in the same way, thus defining a persistent $\mathrm{R} \& \mathrm{D}$ firm as one that has undertaken $R \& D$ activities over at least two consecutive surveys. We can therefore use two different dummy variables to represent a firm's persistent innovative attitude from both an innovation input and output perspective $^{10}$.

In addition, $a_{i t}$ depends on a firm's specific characteristics, i.e., age, being part of a group, sectoral innovative characteristics and location. Thus, we can define $a_{i t}$ as follows:

$$
a_{i t}=\gamma_{0}+\gamma_{1} \boldsymbol{I}_{i t}+\gamma_{2} \boldsymbol{X}_{i t}
$$

where $I_{i t}$ represents a firm's innovation attitude and $X_{i t}$ is a vector of firms' additional characteristics that may affect productivity.

\footnotetext{
${ }^{10}$ See the variable description in Section 3.
} 
The profitability equation is derived while accounting for both traditional SCP effects and firm efficiency view considerations. Additionally, we account for the role of innovation by considering its effect on productivity and, through the latter, on profitability.

Thus the empirical specification may be represented as follows:

$$
\begin{gathered}
y_{i t}=\gamma_{0}+\gamma_{1} \boldsymbol{I}_{i t}+\gamma_{2} \boldsymbol{X}_{i t}+\beta k_{i t}+\tau T_{t}+u_{i t} \\
\operatorname{ros}_{i t}=\alpha_{0}+\alpha_{1} y_{i t}+\alpha_{2} c r 5_{i t} \\
\quad+\alpha_{3} \text { lev }_{i t}+\alpha_{4} \text { intern }_{i t}+\alpha_{5} \text { sect_inntech }_{i t}+v_{i t}
\end{gathered}
$$

where $T_{t}$ is a time dummy common to every firm and refers to a three-year time span and $v_{i t}$ is a one-way error component.

From equations 6 and 7, it appears that the model may be thought of as a recursive system because the matrix of endogenous variables is triangular. Productivity does affect profitability and not vice-versa. In this case, OLS estimates are appropriate, provided that the model is also diagonal recursive, i.e., stochastic disturbances are not correlated $^{11}$.

Specifically, the productivity equation includes the following explanatory variables:

- a dummy variable reflecting a firm's attitude towards persistent (occasional) innovation (pers_tech, pers_tech_ntech,tech,tech_ntech, depending on the specific case), which is included in the $I$ vector of variables in equation 7 ;

- another dummy variable that is also included in the $I$ vector, reflecting whether a firm has persistently (occasionally) undertaken R\&D activities (pers_r\&d or $r \mathscr{E} d$ ). This variable also reflects a firm's absorptive capacity, as discussed in Cohen and Levinthal (1990), and its attitude towards sustaining this capability over time;

- physical capital deepening $(k)$;

- sectoral innovation characteristics (pavitt_mh and pavitt_ml);

\footnotetext{
${ }^{11}$ We also estimated a SURE model to account for such a correlation. The results are very similar to the OLS estimates, thus suggesting that such a correlation is feeble and that the use of OLS is therefore appropriate.
} 
- localisation (nwest, neast, centre and south) and other firm-specific characteristics (age and $g p$ ).

All variables except for physical capital may considered shifting factors for a firm's production function, as we have previously discussed.

The explanatory variables in the profitability equation represent, on the one hand, the SCP mechanism (industry concentration) and, on the other, firms' characteristics related to subjective efficiency (leverage), the ability to sell products on international markets and productivity. This latter variable also reflects a firm's ability to compete through innovation, as productivity is crucially affected - as shown in equation 6 - by a firm's innovative attitude ${ }^{12}$.

We also include a sectoral variable to reflect the possible effects on profitability related to the number of innovative firms in each industry. This is a proxy for new technological opportunities brought about by the increase in an industry's technological knowledge. In this framework, two different mechanisms are operational. On the one hand, we can have a positive effect as an increasing number of sectoral innovators increases a firm's probability of introducing an innovation (epidemic effect) (Mansfield, 1968). This fact may have a positive effect on profitability. On the other hand, this information effect may be offset by a competitive mechanism that implies that the number of competitors in an industry increases, thus squeezing the profits of firms operating in the same market (stock effect) (Karshenas and Stoneman, 1993). Thus, the explanatory variables entering the profitability equation are the following:

- market structure (cr5);

- financial efficiency (lev);

- ability to sell products on international markets (intern);

- productivity $(y)$;

- technological spill-over (sect_inntech).

\footnotetext{
${ }^{12}$ We have not included an innovative dummy reflecting a firm's innovative attitude in the adopted profitability specification, as it was not significant in regressions in which it was included. Indeed, the productivity variable does incorporate a firm's innovative attitude, which therefore determines the non-significant effect of such an innovative dummy variable.
} 


\section{Results}

Table 3 presents the estimates over the entire period while accounting for the fact that the time variable we are considering refers to a three-year time span according to the time interval of the CIS survey, as discussed in Section 3. The estimates that are presented in Table 3 refer therefore to contemporaneous relationships over a three-year time span.

We are aware of the possible endogeneity issue related to the innovative variables. In the Appendix, we present estimates that account for this issue by using predicted values of the innovation variables derived from logit models that explain innovation propensities in terms of firm and sectoral characteristics, following previous studies in which such determinants have been successfully used to derive a firm's innovative behaviour (Bartoloni, 2012).

In addition we have estimated a model in which innovation is treated as predetermined, thus avoiding the possible endogeneity problem determined by the correlation between the error term $u_{i t}$ and the innovative variables. In other words, we introduce a calendar time lag between innovation and the balance sheet information, in that the former precedes the latter. Thus the innovation variables refer to the conventional time $t$ associated to the three-year-time span of the CIS Survey, whereas the economic performance variables refer to the time averages covering three years after the CIS Survey. Thus given a firm's innovative behaviour at time $t$, we estimate productivity and profitability in a successive calendar time ${ }^{13}$. Such estimates generate results that are in line with those presented in Table 3 , which therefore represent the evidence to be analysed.

The estimates are derived by applying random effect (RE) estimation techniques to the system of equations 6 and 7 . Regarding the results, the productivity equation shows that a persistent technological and non-technological attitude increases productivity by nearly $7.4 \%$, compared with firms that do not engage in such behaviour. Firms that introduce technological and non-technological innovations, but not persistently, exhibit a lesser increase in productivity. Thus, being a persistent innovator - using such a broad definition that incorporates nontechnological innovation - provides a significant productivity premium.

It is worth noting that such a premium vanishes if a firm is only a technological innovator, i.e., it does not introduce organisational or

\footnotetext{
${ }^{13}$ These additional estimates are available on request.
} 
Table 3: Firms' economic performance - period 2000-2012

\begin{tabular}{|c|c|c|c|c|c|}
\hline variables & & producti & vity $\mathrm{RE}$ & & profitability $\mathrm{RE}$ \\
\hline & (1) & (2) & (3) & (4) & (5) \\
\hline pers_tech_ntech & $\begin{array}{c}0.0738 * * * \\
{[0.0261]}\end{array}$ & & & & \\
\hline tech_ntech & & $\begin{array}{c}0.0515 * * * \\
{[0.0160]}\end{array}$ & & & \\
\hline pers_tech & & & $\begin{array}{c}-0.0373 \\
{[0.0370]}\end{array}$ & & \\
\hline tech & & & & $\begin{array}{c}0.0251 \\
{[0.0161]}\end{array}$ & \\
\hline $\mathrm{y}$ & & & & & $\begin{array}{l}0.0964 * * * \\
{[0.00336]}\end{array}$ \\
\hline $\operatorname{cr} 5$ & & & & & $\begin{array}{c}0.000366 * * * \\
{[7.83 \mathrm{e}-05]}\end{array}$ \\
\hline sect_inntech & & & & & $\begin{array}{c}-0.00112^{* * *} \\
{[6.57 \mathrm{e}-05]}\end{array}$ \\
\hline lev & & & & & $\begin{array}{l}0.0109 * * * \\
{[0.00145]}\end{array}$ \\
\hline intern & & & & & $\begin{array}{c}-0.0123 * * * \\
{[0.00191]}\end{array}$ \\
\hline $\mathrm{k}$ & $\begin{array}{c}0.180 * * * \\
{[0.00752]}\end{array}$ & $\begin{array}{c}0.181^{* * *} \\
{[0.00742]}\end{array}$ & $\begin{array}{c}0.180 * * * \\
{[0.00750]}\end{array}$ & $\begin{array}{c}0.181 * * * \\
{[0.00740]}\end{array}$ & \\
\hline pavitt_ma & $\begin{array}{l}0.122 * * * \\
{[0.0145]}\end{array}$ & $\begin{array}{l}0.134 * * * \\
{[0.0141]}\end{array}$ & $\begin{array}{l}0.123 * * * \\
{[0.0144]}\end{array}$ & $\begin{array}{l}0.136 * * * \\
{[0.0141]}\end{array}$ & \\
\hline age & $\begin{array}{c}0.0469 * * * \\
{[0.0105]}\end{array}$ & $\begin{array}{c}0.0480 * * * \\
{[0.0105]}\end{array}$ & $\begin{array}{c}0.0471 * * * \\
{[0.0104]}\end{array}$ & $\begin{array}{c}0.0486^{* * *} \\
{[0.0105]}\end{array}$ & \\
\hline pers_r\&d & $\begin{array}{l}0.101 * * * \\
{[0.0159]}\end{array}$ & & $\begin{array}{l}0.117 * * * \\
{[0.0155]}\end{array}$ & & \\
\hline $\mathrm{r} \& \mathrm{~d}$ & & $\begin{array}{l}0.0487 * * * \\
{[0.00912]}\end{array}$ & & $\begin{array}{l}0.0523 * * * \\
{[0.00902]}\end{array}$ & \\
\hline gp & $\begin{array}{c}0.0932 * * * \\
{[0.0109]}\end{array}$ & $\begin{array}{c}0.0998^{* * * *} \\
{[0.0107]}\end{array}$ & $\begin{array}{c}0.0940 * * * \\
{[0.0109]}\end{array}$ & $\begin{array}{l}0.102 * * * \\
{[0.0107]}\end{array}$ & \\
\hline nwest & $\begin{array}{l}0.250 * * * \\
{[0.0236]}\end{array}$ & $\begin{array}{l}0.259 * * * \\
{[0.0233]}\end{array}$ & $\begin{array}{l}0.250 * * * \\
{[0.0236]}\end{array}$ & $\begin{array}{l}0.260 * * * \\
{[0.0233]}\end{array}$ & \\
\hline neast & $\begin{array}{l}0.214^{* * * *} \\
{[0.0230]}\end{array}$ & $\begin{array}{l}0.223 * * * \\
{[0.0230]}\end{array}$ & $\begin{array}{l}0.216 * * * \\
{[0.0230]}\end{array}$ & $\begin{array}{l}0.224 * * * \\
{[0.0229]}\end{array}$ & \\
\hline centre & $\begin{array}{l}0.201 * * * \\
{[0.0275]}\end{array}$ & $\begin{array}{l}0.201 * * * \\
{[0.0275]}\end{array}$ & $\begin{array}{l}0.201 * * * \\
{[0.0275]}\end{array}$ & $\begin{array}{l}0.204^{* * *} \\
{[0.0274]}\end{array}$ & \\
\hline $\mathrm{d} 2000$ & $\begin{array}{l}-0.0103 \\
{[0.0108]}\end{array}$ & $\begin{array}{l}-0.00555 \\
{[0.0109]}\end{array}$ & $\begin{array}{l}-0.0105 \\
{[0.0108]}\end{array}$ & $\begin{array}{l}-0.00503 \\
{[0.0109]}\end{array}$ & \\
\hline d2004 & $\begin{array}{l}-0.0241^{* *} \\
{[0.00987]}\end{array}$ & $\begin{array}{l}-0.0230^{* *} \\
{[0.00992]}\end{array}$ & $\begin{array}{l}-0.0244^{* *} \\
{[0.00988]}\end{array}$ & $\begin{array}{l}-0.0230 * * \\
{[0.00993]}\end{array}$ & \\
\hline d2012 & $\begin{array}{c}-0.0358^{* * * *} \\
{[0.0113]}\end{array}$ & $\begin{array}{c}-0.0347^{* * *} \\
{[0.0112]}\end{array}$ & $\begin{array}{c}-0.0358^{* * *} \\
{[0.0113]}\end{array}$ & $\begin{array}{c}-0.0347^{* * *} \\
{[0.0112]}\end{array}$ & \\
\hline Constant & $\begin{array}{l}4.823 * * * \\
{[0.0556]}\end{array}$ & $\begin{array}{l}4.803 * * * \\
{[0.0550]}\end{array}$ & $\begin{array}{l}4.821 * * * \\
{[0.0555]}\end{array}$ & $\begin{array}{l}4.800 * * * \\
{[0.0551]}\end{array}$ & $\begin{array}{c}-0.450 * * * \\
{[0.0199]}\end{array}$ \\
\hline Observations & 7,923 & 7,923 & 7,923 & 7,923 & 7,923 \\
\hline R-squared & 0.3214 & 0.3215 & 0.3206 & 0.3218 & 0.2945 \\
\hline within & 0.0400 & 0.0412 & 0.0400 & 0.0410 & 0.4164 \\
\hline beetween & 0.3626 & 0.3643 & 0.3621 & 0.3644 & 0.2733 \\
\hline rho & 0.6821 & 0.6820 & 0.6822 & 0.6820 & 0.6651 \\
\hline $\operatorname{sigma} \mu$ & 0.3479 & 0.3476 & 0.3479 & 0.3476 & 0.0533 \\
\hline
\end{tabular}

Robust standard errors in brackets

$* * * \mathrm{p}<0.01, * * \mathrm{p}<0.05, * \mathrm{p}<0.1$

Notes. The variables $y, k$ and age are in log values. Robust standard errors in brackets. ${ }^{* * *} \mathrm{p}<0.01,{ }^{* *} \mathrm{p}<0.05,{ }^{*} \mathrm{p}<0.1$. Rho is an estimation of the contribution of unobserved heterogeneity to the total unexplained variance. Sigma_ $\mu$ is the estimated standard error of the random effect component $\mu_{i}$. 
marketing innovations. This result does not depend on the fact that a firm is persistent in its technological innovation.

A positive effect of a firm's persistent innovating attitude is provided by the impact of the $R \& D$ variable, reflecting such an attitude. The premium in terms of the productivity gain is more than $10 \%$, compared with a corresponding premium for those firms that do not persistently undertake R\&D of almost $5 \%$.

Given these findings concerning the persistent innovation premium, we can discuss the other results in greater detail, concentrating on columns 1 and 2 .

The capital-to-labour ratio $(k)$ implies an elasticity of almost 0.2 , which is consistent with estimates presented in other empirical studies (Mairesse and Sassenou, 1991; Crépon et al., 1998).

We have not estimated the return on knowledge capital, as our choice has been to estimate an equation in which we show the impact on productivity of a persistent technological and non-technological attitude, on the one hand, and of positive and persistent $R \& D$ expenditures, on the other hand, conditional on a set of firm-specific control variables and the capital-to-labour ratio. However, these estimates provide an indirect measure of the impact of knowledge capital, which implies, on the whole, a significant and non-negligible productivity premium comparable with the impact of the capital deepening variable $(k)$.

Another significant impact reflecting technological opportunities available at the industry level is captured by the dummy variable representing an industry's technological level (pavitt_mh). Its impact is significant and relevant because it implies a productivity gain of more than $12 \%$ (column 1) for those firms operating in medium-high-tech sectors according to the Pavitt taxonomy.

The age and group dummy variables show a positive and significant effect, suggesting that older firms have a productivity premium of approximately $5 \%$ and that those firms which belong to a group experience a positive impact on their productivity of more than $9 \%$.

Regional differentials are significant and reflect the disadvantage of the South, in that North and Centre Italy exhibit a gain in productivity that is, on average, more than $20 \%$.

Regarding profitability, we can argue that the effect of the variable reflecting the SCP mechanism (cr5) - although significant - is mild, whereas the other variables reflecting firms' efficiency condition are significant and show non-negligible impacts.

The leverage variable (lev) is significant and positive. A $10 \%$ in- 
crease brings about a 0.1 p.p. increase in profitability, thus signalling that internal resources are crucial in affecting a firm's ability to finance its activity and then earn profits. In other words, as the cost of borrowing increases - in particular because of an increasing economy-wide risk caused by the financial crisis - internal resources play a significant role in affecting firms' investment decisions, as suggested by the pecking order theory (Myers and Majluf, 1984).

A negative sign, i.e., a condition in which highly indebted firms earn higher profits, is plausible but prevailing in financial market conditions in which risk is relatively low and a firm's external debt may amplify the potential gain from investment.

The intern dummy variable represents a proxy for a firm's internationalisation propensity. Its impact is negative and significant but very limited (0.01 p.p.). This evidence suggests that firms that sell products on international markets earn profits slightly lower than those earned by firms that do not internationalise. This observation may be controversial, as one would expect the opposite result, i.e., a positive sign on the coefficient of this dummy variable. However, one can argue that operating on international markets implies additional costs that may be not fully compensated by the potential increase in revenues that the internationalisation process generates.

Table 4: Marginal effects on performance for persistent conjunct innovators (selected variables)

\begin{tabular}{lc}
\hline effects on profitability & \\
\hline y $(+10 \%)$ & +0.9 p. points \\
lev $(+10$ p. point) & +0.1 p. points \\
\hline effects on productivity & \\
\hline & \\
pers_tech_ntech $(=1)$ & $+7.4 \%$ \\
pers_r\&d $(=1)$ & $+10.1 \%$ \\
k $(+1 \%)$ & $+0.2 \%$ \\
pavitt_mh $(=1)$ & $+12 \%$ \\
gp $(=1)$ & $+9.3 \%$ \\
age $(+1)$ & $+4.7 \%$ \\
nwest $(=1)$ & $+25.0 \%$ \\
neast $(=1)$ & $+21.4 \%$ \\
centre $(=1)$ & $+20.1 \%$ \\
\hline
\end{tabular}

Notes. Recall that profitability (ros) is a ratio, whereas productivity $(y)$ is expressed in log values and thus impacts are calculated accordingly. 
The sect_inntech variable shows a very mild and negative impact on profitability, thus signalling that the previously mentioned technological competitive mechanism may prevail, although its effect is feeble.

Table 5: Persistent vs. occasional innovators: fitted values and sample means

\begin{tabular}{|c|c|c|c|c|c|c|c|c|c|c|c|c|}
\hline \multirow{3}{*}{ period } & \multicolumn{6}{|c|}{ complementary innovation } & \multicolumn{6}{|c|}{ only technological innovation } \\
\hline & \multicolumn{2}{|c|}{ persistent } & \multicolumn{2}{|c|}{ occasional } & \multicolumn{2}{|c|}{ (\% diff.) } & \multicolumn{2}{|c|}{ persistent } & \multicolumn{2}{|c|}{ occasional } & \multicolumn{2}{|c|}{ (\% diff.) } \\
\hline & $\hat{y}$ & $\bar{y}$ & $\hat{y}$ & $\bar{y}$ & $\hat{y}$ & $\bar{y}$ & $\widehat{\hat{y}}$ & $\bar{y}$ & $\hat{y}$ & $\bar{y}$ & $\hat{y}$ & $\bar{y}$ \\
\hline $1998-2000$ & 67.2 & 72.9 & 57.6 & 64.2 & 16.6 & 13.6 & 58.7 & 65.0 & - & 55.0 & - & 18.1 \\
\hline $2002-2004$ & 66.0 & 73.0 & 57.8 & 64.1 & 14.3 & 13.9 & 57.5 & 65.3 & - & 55.6 & - & 17.5 \\
\hline $2006-2008$ & 75.4 & 83.4 & 67.2 & 73.7 & 12.3 & 13.2 & 62.4 & 69.0 & - & 63.7 & - & 8.4 \\
\hline $2008-2012$ & 75.8 & 85.8 & 69.1 & 77.1 & 9.7 & 11.3 & 65.4 & 72.0 & - & 65.9 & - & 9.3 \\
\hline $1998-2012$ & 70.8 & 78.5 & 61.6 & 68.5 & 14.9 & 14.6 & 60.5 & 67.5 & - & 58.5 & - & 15.4 \\
\hline
\end{tabular}

\begin{tabular}{|c|c|c|c|c|c|c|c|c|c|c|c|c|}
\hline \multirow{3}{*}{ period } & \multicolumn{6}{|c|}{ complementary innovation } & \multicolumn{6}{|c|}{ only technological innovation } \\
\hline & \multicolumn{2}{|c|}{ persistent } & \multicolumn{2}{|c|}{ occasional } & \multicolumn{2}{|c|}{ (p.p. diff.) } & \multicolumn{2}{|c|}{ persistent } & \multicolumn{2}{|c|}{ occasional } & \multicolumn{2}{|c|}{ (p.p. diff.) } \\
\hline & $\widehat{\mathrm{ros}}$ & $\overline{r o s}$ & $\widetilde{r o s}$ & $\overline{r o s}$ & $\widehat{\text { ros }}$ & $\overline{\overline{r O S}}$ & $\widehat{\text { rOS }}$ & $\overline{r O S}$ & $\widehat{r O S}$ & $\overline{\overline{r O S}}$ & $\widehat{r o s}$ & $\overline{r o s}$ \\
\hline $1998-2000$ & 0.125 & 0.137 & 0.111 & 0.121 & 1.454 & 1.590 & 0.129 & 0.149 & 0.116 & 0.117 & 1.245 & 3.240 \\
\hline $2002-2004$ & 0.132 & 0.134 & 0.116 & 0.111 & 1.675 & 2.300 & 0.123 & 0.127 & 0.121 & 0.121 & 0.170 & 0.611 \\
\hline $2006-2008$ & 0.116 & 0.116 & 0.100 & 0.097 & 1.622 & 1.900 & 0.105 & 0.102 & 0.099 & 0.099 & 0.522 & 0.285 \\
\hline $2008-2012$ & 0.119 & 0.104 & 0.106 & 0.090 & 1.231 & 1.400 & 0.109 & 0.092 & 0.104 & 0.104 & 0.538 & -1.213 \\
\hline $1998-2012$ & 0.123 & 0.123 & 0.109 & 0.107 & 1.417 & 1.600 & 0.117 & 0.119 & 0.113 & 0.113 & 0.441 & 0.646 \\
\hline
\end{tabular}

Notes. $\bar{y}$ and $\overline{r o s}$ : sample means; $\hat{y}$ and rôs: fitted values. Fitted values for productivity referring to only technological innovators are not reported as the corresponding dummy variables are not significant in the estimated equations.

Productivity, which reflects both a firm's efficiency characteristic and a technological attitude, positively enters the profitability equation. Highly productive firms receive a premium in terms of profits corresponding to 0.9 p.p. when productivity increases by $10 \%$.

In the adopted specification we have not included, a dummy variable reflecting the persistent attitude of firms in introducing technological and non-technological innovation, as this variable is not significant when included. It does significantly affect productivity, and through this route it indirectly affects profitability. With reference to complementary innovation (i.e., technological and non-technological) we can observe the difference in productivity and profitability between persistent and non-persistent innovating firms by analysing the data from sample means and fitted values of the regressions (Table 5).

Firms that are persistent innovators experience an average productivity that is nearly $15 \%$ higher with respect to firms that innovate but not persistently. The difference is higher if one considers the average productivity of firms, which also includes non-innovating firms. It is worth noting that such a positive difference is confirmed in comparison with the average productivity of firms that persistently introduce only technological innovation $(+16.9 \%)$, thus underlining - as suggested by 
the estimates - the relevance of the entire process of innovation that necessarily includes new organisational practices and market-oriented behaviour.

This pattern is also confirmed in terms of profitability, in that persistent technological and non-technological innovators exhibit an average profitability that is higher than that of occasional and only technological persistent innovators.

\section{Conclusions}

We have presented an empirical model of the determinants of a firm's productivity and profitability that has enabled us to ascertain the role of factors related to technological and non-technological innovations. In addition, we have underlined how such activities - if undertaken persistently - provide a significant additional increase in a firm's productivity and profitability.

On the contrary, technological innovation alone does not have a significant effect on firm performance. This finding emphasises the relevance of the innovation process, in that skills, learning, organisational adjustments and market orientation- together with technological innovation- determine a firm's performance. Specifically, we find that the productivity premium for those firms that persistently introduce complementary innovations (technological and non-technological) is more than $7 \%$. Firms that do so only occasionally experience a reduction in this premium of approximately 2 p.p. Firms that introduce only technological innovations do not experience any productivity premium.

We also use an input measure of innovative knowledge, related to a firm's R\&D effort. The model's empirical specification includes a dummy variable reflecting the fact that a firm's has (persistently) undertaken $R \& D$ activity. The underlying productivity premium is significant and large, particularly for those firms that persist in their R\&D activity (more than 10\%).

Capital deepening, i.e., the capital-labour ratio, exhibits a positive and significant impact that implies an elasticity of 0.2 . This finding emphasises the role of physical capital accumulation, although a direct comparison with the impact of knowledge capital (R\&D activities) cannot be derived, as we proxy for this effect by using a dummy variable.

Additional firm characteristics are taken into account, suggesting that older firms experience a significant and non-negligible productivity 
premium, which is also acquired by those firms that are part of a group.

Sectoral characteristics related to innovative criteria (Pavitt taxonomy) suggest an increasing relationship between productivity and technological levels.

We also analysed firms' profitability by estimating a profit function that summarises different mechanisms affecting profits. Thus, we have considered the traditional SCP and efficiency view mechanisms, together with the role played by a firm's innovative attitude. The effect of the SCP mechanism (proxied by a concentration index) is negligible, although positive and significant, whereas other firm-level efficiency variables (leverage and the ability to sell products on international markets) show a negative mild impact. This latter effect in particular - although negative - is feeble, suggesting that possible gains from internationalisations may be offset by increasing fixed costs associated with it, particularly for small and medium-sized enterprises.

According to the specified empirical model, productivity reflects a firm's efficiency variable that also incorporates the impact of innovative advances - considered in their extensive definition - on profitability. Its impact on profitability is much larger than that represented by the traditional SCP mechanism, thus underlining the relevance of a firm's innovative attitude in driving its profitability. 


\section{Appendix - Firms' productivity with endoge- nous innovative behaviour (I) - period 2000- 2012}

\begin{tabular}{|c|c|c|c|c|}
\hline \multirow[t]{2}{*}{ variables } & \multicolumn{4}{|c|}{ productivity RE } \\
\hline & (1) & (2) & (3) & (4) \\
\hline \multirow[t]{2}{*}{ pers_tech_ntech } & $0.0582 * * *$ & & & \\
\hline & {$[0.0219]$} & & & \\
\hline \multirow[t]{2}{*}{ tech_ntech } & & $0.0420 * * *$ & & \\
\hline & & {$[0.0124]$} & & \\
\hline \multirow{2}{*}{ pers_tech } & & & 0,0814 & \\
\hline & & & {$[0.0908]$} & \\
\hline \multirow[t]{2}{*}{ tech } & & & & 0.0320 \\
\hline & & & & {$[0.0200]$} \\
\hline \multicolumn{5}{|l|}{$\operatorname{cr} 5$} \\
\hline \multicolumn{5}{|l|}{ sect_inntech } \\
\hline \multicolumn{5}{|l|}{ lev } \\
\hline \multicolumn{5}{|l|}{ intern } \\
\hline \multirow[t]{2}{*}{$\mathrm{k}$} & $0.178^{* * *}$ & $0.177^{* * *}$ & $0.179 * * *$ & $0.179 * * *$ \\
\hline & {$[0.00747]$} & {$[0.00757]$} & {$[0.00743]$} & {$[0.00745]$} \\
\hline \multirow[t]{2}{*}{ pavitt_ma } & $0.122 * * *$ & $0.123^{* * *}$ & $0.128 * * *$ & $0.127 * * *$ \\
\hline & {$[0.0151]$} & {$[0.0153]$} & {$[0.0149]$} & {$[0.0151]$} \\
\hline \multirow[t]{2}{*}{ age } & $0.0491 * * *$ & $0.0465 * * *$ & $0.0493 * * *$ & $0.0494 * * *$ \\
\hline & {$[0.0105]$} & {$[0.0105]$} & {$[0.0105]$} & {$[0.0105]$} \\
\hline \multirow[t]{2}{*}{ pers_r\&d } & $0.0500 * * *$ & & $0.0655^{* * *}$ & \\
\hline & {$[0.0163]$} & & [0.0151] & \\
\hline \multirow[t]{2}{*}{$\mathrm{r} \& \mathrm{~d}$} & & $0.0360^{* * *}$ & & $0.0482 * * *$ \\
\hline & & {$[0.0130]$} & & {$[0.0127]$} \\
\hline \multirow[t]{2}{*}{ gp } & $0.0918^{* * *}$ & $0.0894^{* * *}$ & $0.0936^{* * *}$ & $0.0950 * * *$ \\
\hline & {$[0.0111]$} & {$[0.0112]$} & {$[0.0111]$} & {$[0.0111]$} \\
\hline \multirow[t]{2}{*}{ nwest } & $0.257 * * *$ & $0.249^{* * *}$ & $0.256^{* * * *}$ & $0.253 * * *$ \\
\hline & {$[0.0233]$} & {$[0.0236]$} & {$[0.0233]$} & {$[0.0235]$} \\
\hline \multirow[t]{2}{*}{ neast } & $0.218^{* * *}$ & $0.215^{* * *}$ & $0.222 * * *$ & $0.221 * * *$ \\
\hline & {$[0.0230]$} & {$[0.0231]$} & {$[0.0229]$} & {$[0.0230]$} \\
\hline \multirow[t]{2}{*}{ centre } & $0.204 * * *$ & $0.191 * * *$ & $0.204^{* * *}$ & $0.201 * * *$ \\
\hline & {$[0.0274]$} & {$[0.0278]$} & {$[0.0274]$} & {$[0.0275]$} \\
\hline \multirow[t]{2}{*}{ d2000 } & $-0,00762$ & $-0,0059$ & $-0,00828$ & -0.00168 \\
\hline & {$[0.0109]$} & {$[0.0110]$} & {$[0.0109]$} & {$[0.0112]$} \\
\hline \multirow[t]{2}{*}{ d2004 } & $-0.0226 * *$ & $-0.0229 * *$ & $-0.0235 * *$ & $-0.0217^{* *}$ \\
\hline & {$[0.00995]$} & {$[0.00981]$} & {$[0.00994]$} & {$[0.0101]$} \\
\hline \multirow[t]{2}{*}{ d2012 } & $-0.0368 * * *$ & $-0.0365 * * *$ & $-0.0364 * * *$ & $-0.0354 * * *$ \\
\hline & {$[0.0113]$} & {$[0.0113]$} & {$[0.0113]$} & {$[0.0113]$} \\
\hline \multirow[t]{2}{*}{ Constant } & $8.623 * * *$ & $8.628 * * *$ & $8.612^{* * *}$ & $8.606^{* * *}$ \\
\hline & {$[0.0845]$} & {$[0.0856]$} & [0.0841] & {$[0.0842]$} \\
\hline Observations & 7,923 & 7,923 & 7,923 & 7,923 \\
\hline R-squared & 0.3173 & 0.3173 & 0.3169 & 0.3174 \\
\hline within & 0.0385 & 0.0381 & 0.0382 & 0.0377 \\
\hline beetween & 0.3589 & 0.3593 & 0.3584 & 0.3595 \\
\hline rho & 0.6834 & 0.6837 & 0.6829 & 0.6830 \\
\hline sigma_ $\mu$ & 0.3482 & 0.3483 & 0.3477 & 0.3477 \\
\hline
\end{tabular}

Following Bartoloni (2012), it is possible to estimate a firm's innovation probability using logit models that incorporate explanatory variables causing different firms' innovative behaviours. We use the following explanatory variables: firm's size (size, number of employees, log values), financial efficiency (lev), physical capital deepening $(K)$, industrial group membership $(g p)$, ability to sell products on international markets (intern), market structure (cr5), technological spill-over (sect_inntech), and regional, sectoral and time dummies. We derive predicted probabilities that can then be used to predict the estimated events (pers_tech, pers_tech_ntech, tech, tech_ntech, $R \& D$ and pers_R\&D) used in the productivity regression. 


\section{References}

Aghion, P. and Howitt, P. (1992). A model of growth through creative destruction. Econometrica, 60(2):323-351.

Allen, R. F. (1983). Efficiency, market power, and profitability in american manufacturing. Southern Economic Journal, pages 933-940.

Bain, J. S. (1956). Barriers to new competition: their character and consequences in manufacturing industries, volume 3. Harvard University Press Cambridge, MA.

Bartoloni, E. (2012). The persistence of innovation: a panel data investigation on manufacturing firms. International Review of Applied Economics, 26(6):787-810.

Bartoloni, E. and Baussola, M. (2009). The persistence of profits, sectoral heterogeneity and firms' characteristics. International Journal of the Economics of Business, 16(1):87-111.

Bartoloni, E. and Baussola, M. (2016). Does technological innovation undertaken alone have a real pivotal role? product and marketing innovation in manufacturing firms. Economics of Innovation and New Technology, 25(2):91-113.

Battisti, G., Mourani, A.-G., and Stoneman, P. (2010). Causality and a firm-level innovation scoreboard. Economics of Innovation and New Technology, 19(1):726.

Carpenter, R. E. and Petersen, B. C. (2002). Capital market imperfections, high-tech investment, and new equity financing. The Economic Journal, 112(477):F54-F72.

Cohen, W. M. and Levinthal, D. A. (1990). Absorptive capacity: A new perspective on learning and innovation. Administrative science quarterly, pages 128-152.

Crépon, B., Duguet, E., and Mairessec, J. (1998). Research, innovation and productivity: An econometric analysis at the firm level. Economics of Innovation and new Technology, 7(2):115-158. 
David, P. A. (1992). Knowledge, property, and the system dynamics of technological change. The World Bank Economic Review, 6(suppl 1):215-248.

Delorme Jr., C. D., Kamerschen, D. R., Klein, P. G., and Voeks, L. F. (2002). Structure, conduct and performance: a simultaneous equations approach. Applied economics, 34(17):2135-2141.

Demsetz, H. (1973). Industry structure, market rivalry, and public policy. Journal of Law and economics, 16:1-9.

Frantzen, D. (2003). The causality between R\&D and productivity in manufacturing: an international disaggregate panel data study. International Review of Applied Economics, 17(2):125-146.

Geroski, P. A. (1989). Entry, innovation and productivity growth. The Review of Economics and Statistics, pages 572-578.

Geroski, P. A., Machin, S., and Van Reenen, J. (1993). The profitability of innovative firms. RAND Journal of Economics, 24:198-211.

Geroski, P. A., Van Reenen, J., and Walters, C. F. (1997). How persistently do firms innovate? Research Policy, 26(1):33-48.

Hall, B. H., Lotti, F., and Mairesse, J. (2009). Innovation and productivity in SMEs: empirical evidence for Italy. Small Business Economics, 33(1):13-33.

Hawawini, G., Subramanian, V., and Verdin, P. (2003). Is performance driven by industry-or firm-specific factors? a new look at the evidence. Strategic management journal, 24(1):1-16.

Jones, C. I. (1995). R\&D-based models of economic growth. Journal of political Economy, pages 759-784.

Karshenas, M. and Stoneman, P. L. (1993). Rank, stock, order, and epidemic effects in the diffusion of new process technologies: An empirical model. The RAND Journal of Economics, 24(4):503-528. 
Le Bas, C. and Latham, W. (2006). The Economics of Persistent Innovation. Springer.

Lööf, H. and Heshmati, A. (2002). Knowledge capital and performance heterogeneity: A firm-level innovation study. International Journal of Production Economics, 76(1):61-85.

Mairesse, J. and Sassenou, M. (1991). R\&D productivity: A survey of econometric studies at the firm level. Working Paper 3666, National Bureau of Economic Research.

Mañez, J. A., Rochina-Barrachina, M. E., Sanchis, A., and Sanchis, J. A. (2009). The role of sunk costs in the decision to invest in R\&D. The Journal of Industrial Economics, 57(4):712-735.

Mansfield, E. (1968). Industrial research and technological innovation; an econometric analysis.

Mohnen, P. and Hall, B. H. (2013). Innovation and productivity: an update. Eurasian Business Review, 3(1):47-65.

Mueller, D. C. (1992). The persistence of profits. Springer.

Mueller, D. C. and Cubbin, J. (2005). The dynamics of company profits. Cambridge University Press.

Myers, S. C. and Majluf, N. S. (1984). Corporate financing and investment decisions when firms have information that investors do not have. Journal of financial economics, 13(2):187-221.

Narver, J. C. and Slater, S. F. (1990). The effect of a market orientation on business profitability. The Journal of Marketing, 54(4):20-35.

Peltzman, S. (1977). The gains an losses from industrial concentration. Journal of Law and Economics, 20(2):229-263. 
Printed by Gi\&Gi srl - Triuggio (MB)

March 2016 
Raymond, W., Mohnen, P., Palm, F. C., der Loeff, V., and Schim, S. (2009). Innovative sales, $\mathrm{R} \& \mathrm{D}$ and total innovation expenditures: panel evidence on their dynamics. CESifo Working Paper Series.

Roberts, P. W. (1999). Product innovation, product-market competition and persistent profitability in the US pharmaceutical industry. Strategic Management Journal, 20(7):655-670.

Roberts, P. W. (2001). Innovation and firm-level persistent profitability: a schumpeterian framework. Managerial and Decision Economics, 22(4-5):239-250.

Romer, P. M. (1990). Endogenous technological change. journal of Political Economy, 98(5).

Rouvinen, P. (2002). R\&D-productivity dynamics: Causality, lags, and 'dry holes'. Journal of Applied Economics, 5(1):123-156.

Slade, M. E. (2004). Competing models of firm profitability. International Journal of Industrial Organization, 22(3):289-308.

Stiglitz, J. E. (1987). Learning to learn, localized learning and technological progress. Economic policy and technological performance, pages 125-153.

Stoneman, P. and Kwon, M. J. (1996). Technology adoption and firm profitability. The Economic Journal, 106(437):952-962. 